\title{
Grassroots Democracy and the Participation of Urban People in Central Highlands, Vietnam
}

\author{
Hoang Ba Thinh ${ }^{1 *}$, Doan ThiThanhHuyen ${ }^{2}$ \\ ${ }^{1}$ Hanoi University of Social Sciences and Humanities, Vietnam \\ ${ }^{2}$ Vietnam Women's Academy
}

*Corresponding Author: Hoang Ba Thin, Hanoi University of Social Sciences and Humanities, Vietnam

\begin{abstract}
In many countries around the world, especially the developing countries, the process of urban planning, construction and management with participation of the people/community have shown the advantages and effectiveness of urban development with participation of the people in communities. Based on the research results of the State-level scientific and technological project "Urbanization and the management of the urbanization process in sustainable development in the Central Highlands" (Code TN3/X15), the article will focus on introducing some basic views of the Party and the State of Vietnam on grassroots democracy; then will analyze the participation of urban people in Central Highlands in the process of urban construction, planning and development.
\end{abstract}

The research shows that in the process of urbanization in the Central Highlands; the participation level of the majority of the people is just at the level of the people know, the people discuss; and gradually decreased at the level of the people do and the people check. There exists a difference between the provinces in the Central Highlands about the level of the people's participation in exercising grassroots democracy. The provinces with high urbanization rates, large urban scale and have favorable conditions for economic and socio development (such as in the two provinces of DakLak, Lam Dong, the people's participation is higher than the rest localities (Gia Lai, DakNong, Kon Tum).

Keywords: Grassroots of democracy; Urbanization; Urban planning participation

\section{INTRODUCTION}

The country development platform in the transitional period to socialism (supplemented and developed in 2011) defines "The socialist democracy is the essence of our regime, both a goal and driving force of the country development. To develop and step by step finalize the socialist democracy, ensure democracy is implemented in the real life at each level, in all areas. Democracy is connected closely with discipline and rules, and must be institutionalized by law, which is guaranteed by law".

The Constitution of the Socialist Republic of Vietnam (amended) adopted by the XIII National Assembly in 2013 states that "The Socialist Republic of Vietnam is the People's mastery; all State power belongs to the People"and "The State guarantees and promotes the right to ownership of the People; recognize, respect, protect and guarantee human rights and the citizen rights".

The importance of democracy and the promotion of the People's mastery have been demonstrated in the process of national development and construction. This paper, based on the research results of the State-level scientific and technological project "Urbanization and the management of the urbanization process in sustainable development in the Central Highlands" (Code TN3/X15), will focus on introducing some basic views of the Party and the State of Vietnam on grassroots democracy; then will analyze the participation of urban people in Central Highlands in the process of urban construction, planning and development.

\section{MATERIAL AND RESEARCH METHODS}

The article is based on data from the state-level scientific and technological project "Urbanization and management of urbanization in sustainable development in theCentral Highlands" (Code TN3/X15), implemented in 2015, in 5 provinces of the Central Highlands: Gia Lai, Kon Tum, DakLak, DakNong and Lam Dong. 
The project uses quantitative research method with sociological survey in 5 provinces, each province surveyed 300 household representatives, the total number of samples was 1500.

This study sampled by randomly. After working with the leaders of 5 provinces in the Central Highlands, the author chose communes and wards, from communes and wards to select neighborhoods and villages; finally choose a representative of the household. To select a representative sample of the household, the author used the sampling frame of the 2014 Vietnam Population and Housing Census.

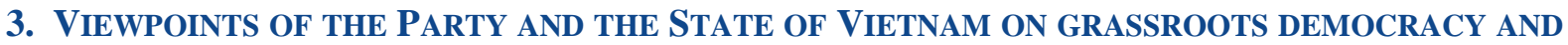 THE PARTICIPATION OF THE PEOPLE IN THE URBAN PLANNING}

\subsection{About Grassroots Democracy}

It can be said that the Instruction No.38-CT/TU dated $18^{\text {th }}$ February 1998 of the Politburo on Developing and implementing the grassroots democracy regulations is the first important document on grassroots democracy in Vietnam. The development of grassroots democracy regulations should be grasped thoroughly in the following guiding points:

- “- Put the promotion of the People's mastery at grassroots level in the overall mechanism of the political system "The Party leadership, the State management and the People's mastery/ownership". Appreciate all three aspects mentioned above, not because of pressing one side but lightly, lower the others.

- Both well promote the representative democracy, enhance the quality and effectiveness of operation of the National Assembly, the Government, the People's Councils and People's Committees at all levels; and well implement the direct democracy regime at grassroots level so that the people discuss and decide important matters that are practical, closely connected to their interests.

- Bringing into play the democracy must be associated with socio-economic development and the people's intellectual development, creating conditions for the expansion of democracy with quality and efficiency.

- Contents of regulations on the promotion of grassroots democracy must be in line with the Constitution and the law, with democratic spirit coupled with discipline, order, power attached to the responsibilities; interests go hand in hand with the obligations; against bureaucracy, orders, and at the same time against anarchy, abuse of democracy to violate the law.

- To associate the process of formulating and implementing the democratic regulations with the administrative reform, revising the mechanisms and policies on administrative procedures which are inappropriate".

Then, the National Assembly and the Government have institutionalized in many legal documents on the implementation of the Regulation on Democracy in some basic forms, such as Resolution No.45/1998/NQ of the Standing Committee of the National Assembly on promulgating the Regulation on implementation of democracy; the Government issued Decree No. 29/1998/ND-CP (May 11, 1998) on the Regulation on implementation of democracy in communes. Resolution No.7/1999/NĐCP (dated 13rd February 1999) on the implementation of grassroots democracy in state enterprises and administrative agencies, etc.

On July $7^{\text {th }} 2003$, the Government issued Decree No. 79/NĐ-CP, promulgating the Regulation on exercise of democracy in commune, replacing Decree No. 29/1998/NĐ-CP. On April $8^{\text {th }} 2005$, the Prime Minister issued Decision No. 80/2005/NĐ-TTg promulgating the Regulation on Investment Supervision of the community. On April 20 $0^{\text {th }}$ 2007, the National Assembly Standing Committee issued Ordinance No. 34/2007/PL-UBTVQH11 on the exercise of democracy in communes, wards and townships.This ordinance clearly stipulates 11 contents which must be disclosed to the People (Article 15, Chapter 2) by three forms of publicity: a) Public posting at the office of the People's Council and People's Committee at commune level; b) Publicity on the commune level radio system; c) Publicity through head of village, head of residential quarter for notification to the local people (Article 6, Chapter 2); the contents, and forms that are directly discussed and decided by the people (Article 11, Section 1, Chapter 3); the contents, forms discussed and voted by the people then decided by the competent authorities (Section 2, Chapter 3); responsibilities (of People's Committee at commune level, Chairman of People's Committee at commune level, Head of Village, Head of 
residential quarter) to implement the contents discussed and decided by the people (Section 3, Chapter 3 ); contents, forms for the people to raise their voice before the competent bodies decide (Article 19, Article 20, Chapter 4); contents supervised by the people (Article 23, Chapter 5), responsibilities of agencies, organizations, individuals in implementation of the people's supervision (Article 25, Chapter 5).This Ordinance also specifies the principles for implementation of democracy at commune level, including: 1) Ensure order and disciplines within the framework of the Constitution and the law; 2) Guarantee the right to know, comment, decide, implement and supervise the implementation of democracy at commune level; 3) Protect the State interests, legitimate rights and interests of organizations and individuals; 4) Publicity and transparency in the implementation of democracy at commune level; 5) Ensure the Party leadership, State management (Article 2));

The Ordinance also clearly defines the responsibilities for implementation of democracy at commune level as follows:

- Within the scope of their tasks and powers, the People's Councils, People's Committees, relevant agencies, organizations, individuals have their responsibility to exercise democracy at commune level;

- People's Councils, People's Committees at commune level are responsible to co-ordinate with the Vietnam Fatherland Front Committees and the Front's member organizations of the same level in implementing democracy at commune level;

- Vietnam Fatherland Front Committees and the Front's member organizations at the commune level have responsibility to supervise the implementation and participate in propagating and advocating the people to exercise democracy at commune level (Article 3));

In addition, there are four behaviors are strictly prohibited when practicing democracy at the commune level:

$>$ Do not implement or violate regulations on implementation of democracy at the commune level;

$>$ Suppressing complainants, denunciations, and petitions related to the implementation of democracy at commune level;

$>$ Covering, obstructing or irresponsible in the settlement of complaints, denunciations and petitions related to the exercise of democracy at the commune level;

$>$ Taking advantage of the implementation of democracy at the commune level to infringe upon national security, social order and safety; infringe upon the interests of the State and the legitimate rights and interests of organizations and individuals (Article 4)).

Therefore, from the Instruction No.30-CT/TW (dated February $18^{\text {th }}$, 1998) of the Politburo (on the development and implementation of democracy regulations at grassroots level, specified by the Decree No.29/ND-CP (dated January $15^{\text {th }}, 1998$ ) and Decree No. 79/ND-CP (dated July $7^{\text {th }}, 2003$ ) of the Government, to the Ordinance No. 34/2007/PL-UBTVQH11 (dated April 20 ${ }^{\text {th }}$, 2007) of the National Assembly Standing Committee is the development step in the awareness of grassroots democracy and the process of institutionalizing the right views, strategic ideology of the Party on grassroots democracy.

In addition, many other legal documents related to the rights and interests of the people, the implementation of democracy regulations have been promulgated, such as: the Law on Election of Deputies to the National Assembly, the Law on the Election of Deputies to the People's Councils, the Law on People's Councils, Law on Anti-Corruption, Law on Thrift Practice, Law on Complaints and Denunciations, Land Law, Law on Promulgation of legal documents. In the renewal period, right from the Sixth Party Congress (1986), our Party has stressed the policy of promoting democracy to create a strong motive for national development. "....in all activities, the Party must thoroughly grasp the idea of "taking the people as root" to develop and promote the right to mastery of the working people" (Vietnam Communist Party, 2006: 3625), the lesson of "Revolution is the career of the masses" is always important. The sixth Congress of the Party (December 1986) set out the way of renewal, bringing our country out of the economic crisis, opening a new stage of development. The sixth Congress of the Party had set out the mechanism of "Party leadership, the People's ownership, State management", and affirmed "Implementation of the slogan people know, people discuss, people do, people check". The document of the sixth Congress also states "People know, people discuss, people do, people check, that is the daily routine of the new society, expressing the people's State self-management regime". 
Promoting the spirit of the sixth Congress, the next Congress all emphasize "Revolutionary belongs to the people, cause by the people, and for the people" and the important task in the revolution is to "develop and step by step finalize the socialist democracy, guarantee that power belongs to the people". It is also a practice of democracy: "The People know, the People discuss, the People do, the People check". President Ho Chi Minh also conceived that "democracy means that the people is the mastery and the people is the owner/democracy means the people's mastery and ownership", "all rights belong to the people", and he affirms: "Democracy is the most precious thing of the people" (Ho Chi Minh, 2011: 457), is the practical benefit of the people, the impulse of the people acting for the country, the nation. The 12th Congress of the Party continues to affirm: "Institutionalize and improve the quality of the forms of exercising direct democracy and representative democracy... Institutionalizing and well implementing the motto "The people know, the people discuss, the people do, the people check" (Communist Party of Vietnam, 2016: 169-170)

\subsection{Viewpoints on Urban Planning with Participation of the People/Community}

In many countries around the world, especially the developing countries, the process of urban planning, construction and management with participation of the people/community have shown the advantages and effectiveness of urban development with participation of the people in communities.In Vietnam, the role of the community has also been emphasized and reflected in some documents of the State such as the Regulation on management of urban planning issued together with Decree No.91/CP dated July $17^{\text {th }}$, 1999 of the Government; the Regulation on Investment and Construction Management issued together with Decree No. 52/1999/ND-CP dated July $8^{\text {th }} 1999$,Decree No. 29/2007 ND-CP dated February $27^{\text {th }}, 2007$ of the Government on urban architectural management; Circular 08/2007 TT-BXD dated September $10^{\text {th }} 2007$ of the Ministry of Construction together with other State documents on guiding the formulation, appraisal and approval of the regulation on management of urban planning. From that, it is clearly seen the importance of participation of the people/community in urban planning.

The Decree $91-\mathrm{CP}$ dated August $17^{\text {th }} 1994$ on the Regulation on Urban Planning Management stated the public disclosure of urban planning information to the public. "The approved Urban planning schemes must be publicized so that the people know and implement". (Article 7)

The participation of the people and community is clearly shown in the Decree 29 - CP dated February $27^{\text {th }} 2007$ on Urban Architectural Management of the Government:

$>$ Communities or individuals have the right to supervise the activities of urban administrations, organizations, individuals in the implementation of the law on construction, the regulations on urban architectural management; in the preservation, exploitation, repair, and embellishment of urban architectural works and landscapes in accordance to the current law provisions.

$>$ Communities or individuals have responsibility and have right to reflect derogations, violations of Regulations on urban architectural management in the area to the administration directly managed by the urban.

$>$ Base for supervision are: legal documents related to urban architecture, detailed plan of 1/500 scale, urban design, model setup based on the approved detailed planning rate, the issued Regulations on urban architectural management, the scheme construction drawing approved and announced by the competent authorities." (Article 25. Community supervision of urban architecture)

\section{RESULTS AND DISCUSSION}

\subsection{Planning and Management of Urban Area in Central Highlands with Participation of the People}

In the political report at the $12^{\text {th }}$ National Communist Party Congress (January 2016), the section "Promote socialist democracy, guarantee the right to mastery of the people" clearly stated: "Continue to promote the socialist democracy to ensure that all State power belongs to the people. Democracy must be fully and seriously exercised in all aspects of social living. Ensure to make the people participate in all steps in the process of decision making relating to the people's living interests" and "Well institutionalizing and implementing the motto "The People know, the People discuss, the People do, the People check, supervise". (Vietnam Communist Party, 2016: 38) 
In this part, we analyze the participation of the People in urban area of Central Highland (including 5 provinces of Kon Tum, Gia Lai, DakLak, DakNong, Lam Dong) in accordance to the spirit of the $12^{\text {th }}$ National Communist Party Congress's Political Report.

With the motto of participation "The People know, the People discuss, the People do, the People check, supervise", in our opinion, the participation level from low to high is: the People know (the lowest participation level); the People discuss, the People do, the People check, and the People supervise (the highest participation level).

\subsubsection{Level of the People Knowing the Information of Urban Planning and Development (The People Know)}

When referring to urban management, one of the indicators to discuss is the level of publicity and transparency of information relating to the infrastructure planning, development. When there are events related to the urban construction or planning, do the authorities inform the people about the relevant activities? The following table will provide the answer:

Table1: Local authorities announce when having roads upgrade, house and project building - by province

\begin{tabular}{|c|c|c|c|c|c|c|c|c|c|c|c|c|}
\hline & \multicolumn{2}{|c|}{ Kon Tum } & \multicolumn{2}{|c|}{ Gia Lai } & \multicolumn{2}{|c|}{ ĐakLak } & \multicolumn{2}{|c|}{ ĐakNong } & \multicolumn{2}{|c|}{ Lam Đong } & \multicolumn{2}{|l|}{ Total } \\
\hline & $\mathrm{N}$ & $\%$ & $\mathrm{~N}$ & $\%$ & $\mathrm{~N}$ & $\%$ & $\mathrm{~N}$ & $\%$ & $\mathrm{~N}$ & $\%$ & $\mathrm{~N}$ & $\%$ \\
\hline Yes & 187 & 62.3 & 300 & 100.0 & 287 & 95.7 & 211 & 70.3 & 275 & 91.7 & 1260 & 84.0 \\
\hline No & 88 & 29.3 & - & - & 2 & 0.7 & 44 & 70.3 & 22 & 7.3 & 156 & 10.4 \\
\hline Don't remember & 25 & 8.3 & - & - & 11 & 3.7 & 45 & 15.0 & 3 & 1.0 & 84 & 5.6 \\
\hline Total & 300 & 100 & 300 & 100 & 300 & 100 & 300 & 100 & 300 & 100 & 1500 & 100 \\
\hline
\end{tabular}

Source: Survey data of the project TN3/X15

The above table shows that, up to $84 \%$ of respondents said the authorities had notice when upgrading roads, building houses, constructions; only $10.4 \%$ said there was no notice and $5.6 \%$ did not remember. Thus, it can be said that the municipal government has well-done to announce (provide information) the local people when there is urban construction and embellishment.

Whenever there have renovations, construction and embellishment of urban areas taken placelocal authorities usually choose the form of meetings of local people groups to inform people in the locality.

Table2: Forms of notification of the authorities when renovating, upgrading, building roads and houses

\begin{tabular}{|l|l|l|}
\hline Forms of notification & $N$ & $\%$ \\
\hline Public radio loudspeaker & 157 & Surve12.5 \\
\hline Village or residential quarter meetings & 1182 & 93.8 \\
\hline Inform via local television, radio channel & 11 & 0.9 \\
\hline
\end{tabular}

Source: Survey data of the project TN3/X15

\subsubsection{The People Participating in Discussion of Urban Planning and Construction (The People Discuss)}

This is one of activities to promote the People's participation in works relating to community development. The research shows that, up to $80.2 \%$ of the respondents said that the local government had consultation from the people if having activities of road upgrading, house and construction building.

By locality, DakLak is the province that the people said their local government had consultation from the people at the highest rate with $95.3 \%$, while in Kon Tum is $49 \%$.

Table3: Local government had consultation from the people if having activities of road upgrading, house and construction building - by province

\begin{tabular}{|l|l|l|l|l|l|l|l|l|l|l|l|l|}
\hline & \multicolumn{2}{|l|}{ Kon Tum } & Gia Lai & \multicolumn{2}{l|}{ DakLak } & \multicolumn{2}{l|}{ ĐakNong } & \multicolumn{2}{l|}{ Lam Đong } & \multicolumn{2}{l|}{ Total } \\
\cline { 2 - 15 } & $\mathrm{N}$ & $\%$ & $\mathrm{~N}$ & $\%$ & $\mathrm{~N}$ & $\%$ & $\mathrm{~N}$ & $\%$ & $\mathrm{~N}$ & $\%$ & $\mathrm{~N}$ & $\%$ \\
\hline Yes & 147 & 49.0 & 274 & 91.3 & 286 & 95.3 & 222 & 74.0 & 274 & 91.3 & 1203 & 80.2 \\
\hline No & 94 & 31.3 & 7 & 2.3 & 2 & 0.7 & 51 & 17.0 & 17 & 5.7 & 171 & 11.4 \\
\hline Don't remember & 59 & 19.7 & 19 & 6.3 & 12 & 4.0 & 27 & 9.0 & 9 & 3.0 & 126 & 8.4 \\
\hline Total & 300 & 100 & 300 & 100 & 300 & 100 & 300 & 100 & 300 & 100 & 1500 & 100 \\
\hline
\end{tabular}

Source: Survey data of the project TN3/X15 
Although up to $80.2 \%$ of respondents said that the government had consulted the people, only $54 \%$ of respondents said that their comments were received by the authorities, and nearly $39 \%$ said their comments and ideas were not absorbed by the government.

Table4: Levels of local government to receive comments from the people when urban planning - by province

\begin{tabular}{|l|l|l|l|l|l|l|l|l|l|l|l|l|l|}
\hline & \multicolumn{2}{|l|}{ Kon Tum } & \multicolumn{2}{l|}{ Gia Lai } & \multicolumn{2}{l|}{ DakLak } & \multicolumn{2}{l|}{ DakNong } & \multicolumn{2}{l|}{ Lam Đong } & \multicolumn{2}{l|}{ Total } \\
\cline { 2 - 17 } & $\mathrm{N}$ & $\%$ & $\mathrm{~N}$ & $\%$ & $\mathrm{~N}$ & $\%$ & $\mathrm{~N}$ & $\%$ & $\mathrm{~N}$ & $\%$ & $\mathrm{~N}$ & $\%$ \\
\hline Yes & 126 & 85.7 & 139 & 50.7 & 107 & 37.4 & 105 & 47.5 & 173 & 63.1 & 650 & 54.0 \\
\hline No & 18 & 12.2 & 130 & 47.4 & 170 & 59.4 & 55 & 24.8 & 92 & 33.6 & 465 & 38.7 \\
\hline Don't remember & 3 & 2.0 & 5 & 1.8 & 9 & 3.1 & 62 & 27.9 & 9 & 3.3 & 88 & 7.3 \\
\hline Total & 147 & 100 & 274 & 100 & 286 & 100 & 222 & 100 & 274 & 100 & 1203 & 100 \\
\hline
\end{tabular}

Source: Survey data of the project TN3/X15

The above table shows that Kon Tum is the province with the highest percentage of authorities receiving the people's opinions, with nearly $86 \%$; the lowest is DakLak with $37.4 \%$, DakNong with $47.5 \%$.

DakLak is also the province have the highest percentage of people saying that the government does not accept the opinions of the people, then followed by Gia Lai with $47.4 \%$.

The government has absorbed the opinion of the people, but how receptive? The following table shows the people's assessment about this:

Table5: Level of local government to receive comments of the people when there have roads upgrading, house and construction building - by province

\begin{tabular}{|l|l|l|l|l|l|l|l|l|l|l|l|l|l|}
\hline & \multicolumn{3}{|l|}{ Kon Tum } & \multicolumn{2}{l|}{ Gia Lai } & \multicolumn{2}{l|}{ DakLak } & \multicolumn{2}{l|}{ DakNong } & \multicolumn{2}{l|}{ Lam Đong } & \multicolumn{2}{l|}{ Total } \\
\cline { 2 - 16 } & $\mathrm{N}$ & $\%$ & $\mathrm{~N}$ & $\%$ & $\mathrm{~N}$ & $\%$ & $\mathrm{~N}$ & $\%$ & $\mathrm{~N}$ & $\%$ & $\mathrm{~N}$ & $\%$ \\
\hline High & 99 & 33.0 & 180 & 60.0 & 52 & 17.3 & 65 & 21.7 & 91 & 30.3 & 487 & 32.5 \\
\hline Medium & 163 & 54.3 & 116 & 38.7 & 160 & 53.3 & 121 & 40.3 & 146 & 48.7 & 706 & 47.1 \\
\hline Low & 17 & 5.7 & 1 & 0.3 & 48 & 16.0 & 32 & 10.7 & 2 & $0, .7$ & 100 & 6.7 \\
\hline Not received & 2 & 0.7 & - & & 1 & 0.3 & 3 & 1.0 & 1 & 0.3 & 7 & 0.5 \\
\hline Don't know & 19 & 6.3 & 3 & 1.0 & 39 & 13.0 & 79 & 26.3 & 60 & 20.0 & 200 & 13.5 \\
\hline Total & 300 & 100 & 300 & 100 & 300 & 100 & 300 & 100 & 300 & 100 & 1500 & 100 \\
\hline
\end{tabular}

Source: Survey data of the project TN3/X15

According to the above table, only $32.5 \%$ of respondents said that the government received the people's opinions at high level. In which, regarding to localities, Gia Lai has the highest rate of government receiving the people's opinions with $60 \%$, lowest is DakLak with $17.3 \%$.

Up to $47 \%$ of respondents said that the government absorbed the people's comments at medium level.

\subsubsection{Participation of the People in the Process of Implementation (The People Do)}

At the level of "the people know "and "the people discuss", the participation of the people in the implementation process of grassroots democracy is passive and low; at the level of "the people do", the people's participation has reached the higher level, the people do not stop at the level know and discuss, but they express their participation via specific actions in implementing programs, construction projects, urban renovation and embellishment. However, the research on urbanization in the Central Highlands shows that the people's participation at the level of "the people do"is not high, just more than one third (36.3\%) of respondents said they did participate in implementing the urban planning and construction projects; less than $10 \%$ compared with the non-participants (46.3\%).

Table6: Participation of the people in Central Highlands in implementing the urban planning and construction projects

\begin{tabular}{|l|l|l|}
\hline Participation & N & $\%$ \\
\hline Yes & 545 & 36.3 \\
\hline No & 694 & 46.3 \\
\hline Don't know/Don't remember & 261 & 17.4 \\
\hline Total & 1500 & 100.0 \\
\hline
\end{tabular}

Source: Survey data of the project TN3/X15

Lam Dong is the province with the highest percentage of the people participating in the urban planning and construction projects (65\%), which is 6 times higher than the participation rate of the people in DakNong (the locality with the lowest rate with $10.3 \%$ ). 
Table7: The participation of the people in Central Highlands in implementing the urban planning and construction projects - by province

\begin{tabular}{|l|l|l|l|l|l|l|l|l|l|l|l|l|l|}
\hline & \multicolumn{2}{|l|}{ Kon Tum } & \multicolumn{2}{l|}{ Gia Lai } & \multicolumn{2}{l|}{ DakLak } & \multicolumn{2}{l|}{ DakNong } & \multicolumn{2}{|l|}{ Lam Dong } & \multicolumn{2}{l|}{ Total } \\
\cline { 2 - 16 } & $\mathrm{N}$ & $\%$ & $\mathrm{~N}$ & $\%$ & $\mathrm{~N}$ & $\%$ & $\mathrm{~N}$ & $\%$ & $\mathrm{~N}$ & $\%$ & $\mathrm{~N}$ & $\%$ \\
\hline Yes & 68 & 22.7 & 120 & 40.0 & 131 & 43.7 & 31 & 10.3 & 195 & 65.0 & 545 & 36.3 \\
\hline No & 175 & 58.3 & 175 & 58.3 & 137 & 45.7 & 115 & 38.3 & 67 & 22.3 & 694 & 463 \\
\hline $\begin{array}{l}\text { Don't know/ Don't } \\
\text { remember }\end{array}$ & 32 & 10.7 & 5 & 1.7 & 32 & 10.6 & 154 & 51.4 & 38 & 12.7 & 261 & 17.4 \\
\hline Total & 300 & 100 & 300 & 100 & 300 & 100 & 300 & 100 & 300 & 100 & 1500 & 100 \\
\hline
\end{tabular}

Source: Survey data of the project TN3/X15

During the implementation process, nearly $29 \%$ of respondents said they participated in the management and maintenance of urban construction, renovation and embellishment works, while there are over half of the people do not participate in this activity.

Table8: Participation of the people in Central Highlands in management and maintenance

\begin{tabular}{|l|l|l|}
\hline Participation & $\mathrm{N}$ & $\%$ \\
\hline Yes & 430 & 28.7 \\
\hline No & 754 & 50.3 \\
\hline Don't know/Don't remember & 316 & 21.1 \\
\hline Total & 1500 & 100.0 \\
\hline
\end{tabular}

Source: Survey data of the project TN3/X15

There exist differences between provinces in the Central Highlands regarding the participation into urban management and maintenance works. DakLak is the province with the highest rate of participation into the management and maintenance work (44\%), then followed by Lam Dong with $37.3 \%$; the lowest rate is Kon Tum province with the rate of $2 \%$ only.

Table9: Participation in the management and maintenance of the people in the Central Highlands - by province

\begin{tabular}{|l|l|l|l|l|l|l|l|l|l|l|l|l|l|}
\hline & \multicolumn{2}{|l|}{ Kon Tum } & Gia Lai & \multicolumn{2}{l|}{ ĐakLak } & \multicolumn{2}{l|}{ DakNong } & \multicolumn{2}{l|}{ Lam Đong } & \multicolumn{2}{l|}{ Total } \\
\cline { 2 - 14 } & $\mathrm{N}$ & $\%$ & $\mathrm{~N}$ & $\%$ & $\mathrm{~N}$ & $\%$ & $\mathrm{~N}$ & $\%$ & $\mathrm{~N}$ & $\%$ & $\mathrm{~N}$ & $\%$ \\
\hline Yes & 6 & 2.0 & 142 & 47.3 & 132 & 44.0 & 38 & 12.7 & 112 & 37.3 & 430 & 28.7 \\
\hline No & 245 & 81.7 & 153 & 51.0 & 101 & 33.7 & 111 & 37.0 & 144 & 48.0 & 754 & 50.3 \\
\hline $\begin{array}{l}\text { Don't know/Don't } \\
\text { remember }\end{array}$ & 49 & 16.3 & 5 & 1.7 & 67 & 22.3 & 151 & 50.3 & 44 & 14.7 & 316 & 21.1 \\
\hline Total & 300 & 100 & 300 & 100 & 300 & 100 & 300 & 100 & 300 & 100 & 1500 & 100 \\
\hline
\end{tabular}

Source: Survey data of the project TN3/X15

\subsection{Supervision of the People (The People Check, Supervise)}

Our research found that nearly $37 \%$ of respondents said they were involved in monitoring and evaluating the urban construction, renovation, embellishment projects, compared with $45.2 \%$ of nonparticipants.

Table10: Participation of the people in Central Highlands in monitoring and evaluation activities

\begin{tabular}{|l|l|l|}
\hline Participation & $\mathrm{N}$ & $\%$ \\
\hline Yes & 549 & 36.6 \\
\hline No & 678 & 45.2 \\
\hline Don't know/Don't Remember & 273 & 18.2 \\
\hline Total & 1500 & 100.0 \\
\hline
\end{tabular}

Source: Survey data of the project TN3/X15

By localities, nearly $67 \%$ of people in DakLak said they are involved in the process of monitoring and evaluation of urban construction, renovation, embellishment; while this rate in Gia Lai is approximately $45 \%$. The locality with the lowest percentage of people participating in monitoring and evaluation is DakNong with $9 \%$, followed by Kon Tum with $23 \%$. 
Table11: Participating in monitoring and evaluation of people in Central Highlands - by province

\begin{tabular}{|l|l|l|l|l|l|l|l|l|l|l|l|l|l|l|}
\hline & \multicolumn{2}{|l|}{ Kon Tum } & \multicolumn{2}{l|}{ Gia Lai } & \multicolumn{2}{|l|}{ DakLak } & \multicolumn{2}{|l|}{ DakNong } & \multicolumn{2}{l|}{ Lam Đong } & \multicolumn{2}{l|}{ Total } \\
\cline { 2 - 15 } & $\mathrm{N}$ & $\%$ & $\mathrm{~N}$ & $\%$ & $\mathrm{~N}$ & $\%$ & $\mathrm{~N}$ & $\%$ & $\mathrm{~N}$ & $\%$ & $\mathrm{~N}$ & $\%$ \\
\hline Yes & 69 & 23.0 & 134 & 44.7 & 200 & 66.7 & 27 & 9.0 & 119 & 39.7 & 549 & 36.6 \\
\hline No & 193 & 64.3 & 162 & 54.0 & 68 & 22.7 & 115 & 38.3 & 140 & 46.7 & 678 & 45.2 \\
\hline $\begin{array}{l}\text { Don't know/Don't } \\
\text { remember }\end{array}$ & 38 & 12.7 & 4 & 1.3 & 32 & 10.7 & 158 & 52.7 & 41 & 13.7 & 273 & 18.2 \\
\hline Total & 300 & 100 & 300 & 100 & 300 & 100 & 300 & 100 & 300 & 100 & 1500 & 100 \\
\hline
\end{tabular}

Source: Survey data of the project TN3/X15

In order for "the People do", the people actively participate in the work of the country, the locality, participate in social management, want to promote the right to people's mastery, it must be on the basis of "the People know" and "the People discuss" thoroughly. It is important to implement the real grassroots democracy in order to build up trust among the people and strengthen the social belief, and to avoid grassroots democracy in a formalistic way

For "the People know", it is a must for all policies, plans, and tasks of the Party organizations, the State, government at levels, mass organizations, as well as grassroots agencies and units to be publicity and transparency. The people must be informed timely, accurately, fully and multidimensionally. The people have their right to request for being provided with information in all aspects (except for national confidentiality issues), such as the Law on Access to Information 2016 (which takes effects on July $1^{\text {st }} 2018$ ).

The people do not only have their right to "know", "discuss", "do" but also have their rights to "check and supervise" activities in their locality and community. The people participating in checking, supervising the activities and works of their State and locality is the highest expression of the "democracy" spirit and their real ownership. The people are to check, supervise will help prevent and reduce corruption, waste and bureaucracy while ensuring good quality of works, plans, constructions, project, etc.

To be able to promote the strength/power of the people in the words of President Ho Chi Minh in the article of "Mass mobilization" "In short, power and force are in the people", it is essential to fully and accurately implement the spirit of the $12^{\text {th }}$ Communist Party Congress Documents "Promotion of democracy must be closely linked to the discipline, to the strengthening of legislation, promotion of civic responsibility and social morality".Criticism of radical democratic expressions, formalistic democracy. Strictly treat all acts of abusing democracy to cause disorder in security, politics, social order and safety and acts of violating the people's democracy and the people's right to mastery".

\section{CONCLUSION}

The research shows that in the process of urbanization in the Central Highlands; the process of institutionalization and implementation of the motto "The People know, the people discuss, the people do, the people check and supervise" has been implemented to a certain extent. Participation of the people at the grassroots level - an important indicator of practicing grassroots democracy - has been implemented fully at all levels, from the low to high level of participation, from "the people know, the people discuss" to "the people do" and "the people check, supervise".

However, the participation level of the majority of the people is just at the level of the people know, the people discuss; and gradually decreased at the level of the people do and the people check. Notably, urban people participating in providing their much opinions, but the percentage of authorities receiving opinions of "the people discuss" is very low. This shows that the urban government has not really looked for, listened to the people's opinions in the process of urban planning and construction for the Central Highlands.

There exists a difference between the provinces in the Central Highlands about the level of the people's participation in exercising grassroots democracy. The provinces with high urbanization rates, large urban scale and have favorable conditions for economic and socio development (such as in the two provinces of DakLak, Lam Dong, the people's participation is higher than the rest localities (Gia Lai, DakNong, Kon Tum).

In addition, the urban management staff and urban authorities in DakLak and Lam Dong also have higher qualified human resources than the rest of the Central Highlands.

Our research found that ethnicity (ethnic minorities) does not affect the participation of grassroots democracy in the urban areas of the Central Highlands. 
From the research results, it can be said that: for urban people (as the developed area), the level of participation and implementation of grassroots democracy is just at such level, people in rural areas, in remoted and distant areas might have difficult to reach such participation level of the urban people. This practice requires the process of social management in general and urban management in particular to have appropriate solutions and conditions to institutionalize the motto "The People know, the People discuss, the People check and supervision" that is increasingly widespread and practiced at grassroots levels such as in communes, wards, and towns.

\section{REFERENCE}

[1] Directive No.38 - CT/TU dated February $18^{\text {th }} 1998$ of the Politiburo on Developing and implementation of grassroots democracy regulation

[2] Platform of building the country in the transitional period to socialism (supplemented and developed in 2011); National Political Publishing House, Hanoi

[3] Vietnam Communist Party: The $12^{\text {th }}$ National Communist Party Congress, National Political - Truth Publishing House, H, 2016

[4] The Vietnam Communist Party: 2006: The Complete Party Document, the National Political Publishing House, Hanoi

[5] The Constitution of the Socialist of Vietnam in 2013; the National Political Publishing House, Hanoi.

[6] Ho Chi Minh. 201. Full set, episode 10; National Political - Truth Publishing House, Hanoi

[7] Hoang Ba Thinh. 2016. Urbanization and development of the Central Highlands (monograph book); the Hanoi National University Publishing House.

[8] Hoang Ba Thinh. 2015. Urbanization and management of the urbanization process in sustainable development in Central Highlands; National Scientific and Technology Project, (the Central Highlands Program 3); Code TN/X15

[9] Decree No. 29 - CP dated February $27^{\text {th }} 2007$ of the Government on Urban Architectural Management.

[10] Decree No. 91 - CP dated August $17^{\text {th }} 1994$ on Urbanplanning management regulations.

[11] The National Assembly of the Socialist Republic of Vietnam, 2007. Ordinance No.34/207/PLUBTVQH11 on the Implementation of democracy in communes, wards, and townships.

\section{AUTHORS' BIOGRAPHY}

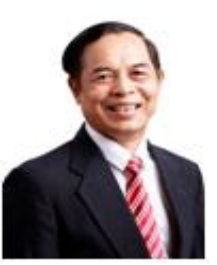

Hoang Ba Thinh, Professor of Sociology. He is currently a senior lecturer in the Faculty of Sociology, Hanoi University of Social Sciences and Humanities (USSH). Professor Hoang Ba Thinh is Head of Gender and Family Department; and Director of Research Center for Gender, Population, Environment and Social Affairs, USSH. He is currently Honor Director of Vietnam Taiwan Research Institute, National Dong Hwa University, Taiwan.

Professor Hoang Ba Thinh's arrears of research and teaching include, Developmental Theory, Sociology of Family, Sociology of Gender, Sociology of Health, Medical Social Work. Other areas of interests and expertise are evaluation training and research in Gender development projects, girls and gender education. Professor Hoang Ba Thinh has published widely in the above mentioned areas. $\mathrm{He}$ is a Consultant for various governmental and non-governmental organizations in Vietnam.

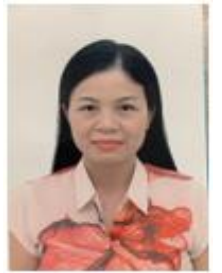

Doan Thi Thanh Huyen. PhD on Sociology, she is Vice Dean of the Faculty of Social Work, Vietnam Women's Academy. Dr. Doan Thi Thanh Huyen's areas of research and teaching include, General Sociolgy; Sociology of Family; Family Studies; Population and Development; Social Work for Children; Social Work Management.

Dr. Doan Thi Thanh Huyen has published widely in her areas of interests and consulted for various governmental and non-governmental organizations in Vietnam.

Citation: Hoang Ba Thinh, Doan ThiThanhHuyen. "Grassroots Democracy and the Participation of Urban People in Central Highlands, Vietnam". International Journal of Humanities Social Sciences and Education (IJHSSE), vol. 6, no.6, 2019, pp. 84-92. Doi: http://dx.doi.org/ 10.20431/2349-0381.0606010.

Copyright: (0) 2019 Authors. This is an open-access article distributed under the terms of the Creative Commons Attribution License, which permits unrestricted use, distribution, and reproduction in any medium, provided the original author and source are credited. 